\title{
PROFESSOR AMÉRICO, O HISTORIADOR DA LONGA DURAÇÃO
}

\section{Norberto Dallabrida*}

No dia 7 de outubro do corrente ano, o professor Américo da Costa Souto completaria 80 anos. Sob o impacto de sua morte, ocorrida em meados deste ano, ele foi lembrado como o precursor na renovação dos estudos históricos em Santa Catarina. A sua obra de vanguarda merece ser colocada em destaque e rememorada por sua relevância no campo historiográfico.

O pioneirismo do professor Américo na compreensão da história deve-se ao fato de ele se apropriar das proposições historiográficas da chamada Escola dos Annales e, particularmente, de Fernand Braudel. A Escola dos Annales foi um movimento historiográfico francês que ganhou visibilidade a partir de 1929, com o lançamento da revista homônima. A escola francesa - como gostava de chamá-la o professor Américo - procurou superar a História Tradicional, focada na descrição de acontecimentos históricos, pela análise de processos sociais em perspectiva temporal. Professor da USP entre 1935 e 1937, Braudel converteu-se na principal liderança dos Annales no pós-guerra, destacando-se por pensar além dos fatos pontuais, conjunturas e estruturas históricas, ou seja, tempos de média e de longa duração, bem como por contaminar a História com outras disciplinas.

É a partir da clave braudeliana que o professor Américo ministrava as suas aulas e escrevia os seus ensaios. Como docente das disciplinas História Moderna e Contemporânea na UFSC, entre 1963 e 1991, ele trabalhava a multiplicidade temporal e integrava à leitura histórica diversas disciplinas, especialmente a Geografia, a Economia e a Sociologia. Em primeiro lugar, focalizava a Civilização Ocidental, plasmada pelo cristianismo, como “longuíssima duração”. O Ocidente era dividido em estruturas, isto é, durações longas - as

\footnotetext{
*Doutor em História Social pela Universidade de São Paulo. Professor da Universidade do Estado de Santa Catarina. Autor de “A fabricação escolar das elites” (Editora Cidade Futura). E-mail: norberto@udesc.br
} 
idades média, moderna e contemporânea - e estas desdobradas em tempos menores, as conjunturas, que podem durar séculos ou décadas. Os acontecimentos eram situados na superfície dos tempos mais longos.

Nas suas aulas, embora estimulasse os alunos a "identificar a hierarquia das durações históricas (estruturais, conjunturais e factuais)”, o professor Américo chamava a atenção para os fatores permanentes da Civilização Cristã Ocidental. Ele propunha exercícios braudelianos, que consistiam em compreender um acontecimento datado nas suas conjunturas e estruturas históricas. As revoluções (francesa, russa e outras) eram analisadas a partir de quatro momentos: o início moderado, a radicalização à esquerda, a volta ao centro e a guinada à reação. Nas suas aulas meticulosamente preparadas, o velho mestre braudeliano movimentava a multiplicidade temporal, mas acabava por enfatizar as permanências históricas. Para tanto, citava com frequência o personagem Tancredi do romance Il gattopardo, de Giuseppe Tomase di Lampeduza, que afirma: "Em história as coisas mudam para continuarem como estão”.

De outra parte, os ensaios históricos do professor Américo também eram construídos à luz da temporalidade múltipla. Ele escreveu sobre vários temas, como a Revolução Francesa, o mundo russo e o expressionismo alemão, mas destacou-se por pensar historicamente a economia catarinense. O livro "Evolução Histórico-Econômica de Santa Catarina: estudos das alterações estruturais (século XVII-1960)”, publicada em 1980 pelo Centro de Assistência Gerencial de Santa Catarina (CEAG/SC), contou com a participação de economistas e a leitura histórica do professor Américo da Costa Souto - o autor invisível -, que lhe deu um tom braudeliano.

Essa obra seminal propõe uma estrutura básica para a economia catarinense entre o século XVII e a década de 1960: a satelização em torno de centros nacionais, especialmente o eixo Rio_-_São Paulo, e a fragmentação em zonas geoeconômicas. Essa longuíssima duração é formada por três estruturas menores - a economia subsidiária e primário exportadora, a “indústria tradicional” e a "indústria dinâmica” - divididas por momentos conjunturais. A geografia é integrada ao olhar histórico sobre a economia catarinense, de forma que o livro visualiza seis zonas geoeconômicas especializadas, como a indústria têxtil no Vale do Itajaí e a produção de carvão na região sul. Esse olhar sobre a descentralização do Estado de Santa Catarina é inusitado na historiografia catarinense, podendo ser pensado para outros aspectos da vida social.

A produção histórica do professor Américo representou uma ruptura significativa em relação à história “tradicional”, praticada por boa parte dos historiadores. O seu caráter 
inovador deve-se ${ }_{2}$ sobretudo, à inteligência de pensar tempos históricos diferentes, dando relevo às permanências. Por isso, quando vi a fotografia de Fernand Braudel com a legenda "I 'historien de la longue durée" na Biblioteca da École des hautes études en sciences sociales (EHESS), pensei que ela caberia ao professor Américo. Neste momento de memórias, estou convencido que a alcunha dada ao mestre francês é apropriada ao seu discípulo catarinense. 